\section{REPORTS \\ on}

THE NURSING AND ADMINISTRATION OF PROVINCIAL WORKHOUSES AND INFIRMARIES

Sprcial Commission of the "British Medical Jodrnal."

\section{LII.-SMALLBURGH, NORFOLK.}

Ir seems that this rambling old house once belonged to a county magnate,' wKb turned it into a houee of industry, gathering into it such weavers as were not in a position to earn their living in their cottages. Some of the floors show the marks of weavers' looms, and the hooks that they used are still in the walls. The staircases have wide easy steps and spacious landings, contrasting most pleasantly with the narrow winding stairs of the workhouses of later date, neither serviceable for the living, nor convenient for transporting the dead.

The outward aspect of the house is that of ${ }^{2}$ barracks. It is built of red brick, with few and small windows towards the road; it has accommodation for 800 inmates, but only 45 were on the books at the time of our visit, and the master said that 70 would be the largest number, even in the winter. A large part of the house is therefore shut up.

\section{The Old Men's Infirmary}

is on the ground floor; it is one of the old rooms unaltered; windows small, and on one side only; low pitched roof with open rafters. There were about eight men in bed. A dreary day-room is close to the ward, well supplied with benches, but there were very few armchairs, either in day room or ward. The one redeeming feature was a pleasant and goodsized garden, where such of the old men as can get out may sit and smoke.

\section{THR OLD WOMEN}

are on the first 'floor in two rooms, a day room and an inner room as the ward. Here are more comforts : a good supply of armchairs and a horsehair couch, cushions, a table cover. and growing plants gave a more homelike air. The old ladies need such compensations, as they are rarely able to go up and down stairs, and moreover their piece of ground was not so well cared for as that of the men. There were two curtains to each bed. The bedding throughout is flock; in many cases we noticed that it was lumpy and wanted teasing out: :

There is a Nurse,

but she is untrained, and is getting on in years; there is no night nurse, only paupers sleeping in the wards at night. The male and female infirmaries are some distance apart. The class of cases is such as is usual in country workhouses, paralysed and bedridden patients, helpless as children, and requiring at the least as much attendance; whatever they may receive by day it is clear that they get none at night. There were about twenty patients at the time of our visit.

\section{THE NURSERY}

is a large drears room near the female infirmary. A baby in a cradle was being tended by a deaf and dumb woman, and another infant was in the arms of an imbecile. A flight of stairs from this room led to the night nursery. Here we found an infant lying in a large bed placidly sucking a tube feeding bottle, and an older child in a wooden cradle. The latter was, we were told, an orphan being brought up (?) by the guardians. It was well that these infants were so capable of looking after themselves, for the deaf and dumb woman would, of course, have heard no sound, and the in tellect of the imbecile could hardly be reckoned on in an emergency. When will guardians recognise their responsibility for these infants? We would suggest that the orphan should be pat out to nurse in the village.

The Lying-IN WARD

is on the first floor near to the nurse's room,"a small room containing two beds; it is not often used.

\title{
SANITARY ARRANGEMBNTS
}

are non-existent. In the wards are the usual commodes, and outside, at some distance from the wards, are privies, too far to be of any avail for the old and infirm. The commodes of course are not emptied at night. No water is laid on inside the house; there are consequently no baths. The wards are ventilated by the windows, supplemented by Tobin's system, but the tubes are not placed at the right height in the walls.

The well-cultivated garden, plentifully stocked with vegetables and fruit trees. suggested a varied diet for the sick, with jam to take the place of butter at times. We hope that the inmates share in the produce before it is sold by the guardians for the relief of the rates.

Recommendations.

When we find such an antiquated house in a sparselypeopled district, we wonder if it is worth while to maintain such an establishment for so few. Could not the inmates be placed in another house, with no disadvantage to themselves and a manifest saving to the ratepayers? A certain amount of money would need to be spent on the present house to make it sanitary and workable. The master told us that he had the greatest difficulty in finding able-bodied paupers to do the work, and the fact that the infants are in the charge of an imbecile and of a deaf mute bears out his statement.

A REPORT ON THE

MILK SUPPLY OF LONDON BY $\Delta$

SPECIAL ANALYTICAL AND BIOLOGICAL COMMISSION.

\section{REPORT UPON THE ANALYSIS OF TWENTY SAMPLES OF MILK.}

By CHARLES E. CASSAL, F.I.C.,

Public Analyst for Kensington, St. George Hanover \&quare, etc. SECOND REPORT.

I CERTIFY that I have analysed 20 samples of milk, numbered from 31 to 50 on behalf of the British Medical Association Special Milk Commission. From a consideration of the results of $\mathrm{my}$ analyses I have arrived at the understated opinions concerning the composition of the samples (see Table). It has been explained in a previous report (No. 1) that 3 per cent. of fat is the lowest amount which should be present in a sample to which the term "milk" can still justifiably be applied, and that a purchaser ought fairly to receive not less than 3.5 per cent. of fat in an article sold to him as milk.

A sample of milk purchased in the ordinary way from a well-known dairy company (the Aylesbury) has already been reported as containing 4.2 per cent. of fat. Another sample purchased from a large firm showed 5.1 per cent. of fat, but was found to contain boric acid. The amount of fat, however, will serve as a further example.

In those cases where the fat found was below 3.5 per cent. but not below 3 per cent, the percentage of fat deficiency on the 35 standard is shown. Inasmuch as deficiency of fat is now generally brought about by the admixture of separated milk, which contains practically no fat, with a milk of genuine composition, it is convenient to regard milks deficient in fat as made up of " milk devoid of fat" and milk of genuine composition. In those cases where the amount of fat found was below 3 per cent. the calculations have been made on the lower, or 3 per cent. limit, a fact which is indicated by the genuine milk present being reported as " milk of genuine composition but of the poorest quality." 


\begin{tabular}{|c|c|c|c|c|c|c|c|c|}
\hline & \multicolumn{8}{|c|}{ Results of Analysis. } \\
\hline & & & & $\mathbf{A}$ & $\mathbf{B}$ & C & $\mathbf{D}$ & $\mathbf{E}$ \\
\hline 安 & 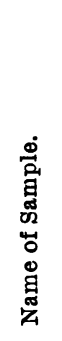 & 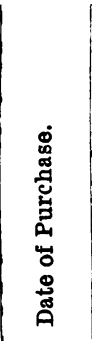 & $\begin{array}{l}\stackrel{+}{0} \\
\stackrel{\Xi}{\Xi} \\
\ddot{A}\end{array}$ & 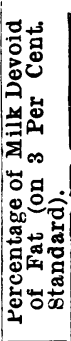 & 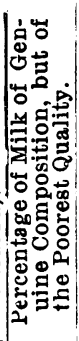 & 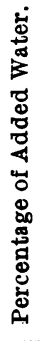 & 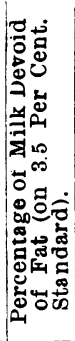 & Remarks. \\
\hline 31 & Milk & $\begin{array}{l}1895 \\
\text { July } 8\end{array}$ & $\begin{array}{c}\text { North } \\
\text { Kensing- } \\
\text { ton and } \\
\text { Notting } \\
\text { Hill }\end{array}$ & 25 & 75 & - & - & - \\
\hline 32 & " & " & , & $\overline{-}$ & 94 & 6 & $\overline{14}$ & $\longrightarrow$ \\
\hline $\begin{array}{l}33 \\
34\end{array}$ & $"$ & $"$ & $"$ & $\overline{37}$ & $\overline{63}$ & - & 14 & $\bar{Z}$ \\
\hline 35 & $"$, & $"$, & $"$ & 21 & 79 & - & - & Tampin \\
\hline 36 & $"$ & $"$ & ", & - & - & - & - & $\begin{array}{l}\text { Genuine composition ; } \\
\text { fair quality. }\end{array}$ \\
\hline 37 & , & July 17 & $\begin{array}{c}\text { North } \\
\text { Kensing- } \\
\text { ton }\end{array}$ & 一 & 94 & 6 & - & tans quante \\
\hline 38 & " & $"$ & $"$ & - & - & - & - & $\begin{array}{l}\text { Boric acid present, } \\
\text { otherwise } \\
\text { fair quality }\end{array}$ \\
\hline 39 & " & ", & " & 5 & 95 & - & $\overline{10}$ & Boric acid present. \\
\hline $\begin{array}{l}40 \\
\mathbf{4 1}\end{array}$ & $"$ & ", & ", & $\overline{14}$ & $\overline{86}$ & $\overline{-}$ & 13 & $\begin{array}{l}\text { "Working } M \text { on's } \\
\text { Stores." }\end{array}$ \\
\hline 42 & " & & & - & - & - & 10 & - \\
\hline 43 & $"$ & July 18 & $\begin{array}{c}\text { Isling- } \\
\text { ton, } \\
\text { Clerken- } \\
\text { well, and } \\
\text { Hollo- } \\
\text { way }\end{array}$ & - & - & - & - & $\begin{array}{l}\text { Genuine composition ; } \\
\text { fair quality. }\end{array}$ \\
\hline 44 & " & " & " & - & 96 & 4 & - & Canming \\
\hline 45 & $"$ & $"$ & ", & - & - & - & - & $\begin{array}{l}\text { Genuine composition } \\
\text { fair quality. }\end{array}$ \\
\hline 46 & " & " & ", & - & - & - & - & $\begin{array}{l}\text { Genuine composition } \\
\text { fairly quality. }\end{array}$ \\
\hline 47 & " & " & , & - & - & - & - & $\begin{array}{l}\text { Genuine composition; } \\
\text { fair quality. }\end{array}$ \\
\hline 48 & " & " & ", & - & - & - & - & $\begin{array}{l}\text { Genuine composition; } \\
\text { fair quality. }\end{array}$ \\
\hline 49 & " & $"$ & ", & - & - & - & - & $\begin{array}{l}\text { Genuine composition; } \\
\text { fair quality. }\end{array}$ \\
\hline 50 & " & " & " & - & - & - & - & $\begin{array}{l}\text { Boric acid present, } \\
\text { otherwise genuine; } \\
\text { fair quality. }\end{array}$ \\
\hline
\end{tabular}

\section{GAS LIGHTING CONSIDERED FROM A HYGIENIC POINT OF VIEW.}

THF observation has long been made that the air of a room lighted by gas becomes unpleasant and oppressive, acquiring a disagreeable smell, and irritating the mucous membrane of the larynx and windpipe. These effects are partly due to incomplete combustion resulting from the use of defective burners, and with the object of studying the question whether gas burnt in good burners is prejudicial to health, Professor Geelmuyden has carried out a long series of experiments at the Physiological Institute of Christiania University, with results which are decidedly favourable to gas as it is used in that town. A full account of these experiments is published in the Gas World, from which the following summary of the more interesting details is taken :

The average composition by volume of the gas used was 47 per cent. hydrogen, 36 per cent. marsh gas, 4 per cent. heavy hydrocarbons and benzine, 8 per cent. carbonic oxide, 2 per cent. carbonic acid, 2 to 3 per cent. nitrogen, with from 304 to 347 grains of sulphur in all forms per 1,000 cubic feet. In the complete combustion of such a mixture the products are carbonic acid and water vapour, together with a little nitrogen, some sulphurous acid which soon becomes sulphuric acid in damp air, and some traces of oxygen compounds of nitrogen.

Three types of burners were used in the experiments : the ordinary slit burner, the argand, and the incandescent burner, and when onee it had been ascertained that with good ordinary burners combustion is complete, the questions to be determined had reference only to carbonic oxide, arsenious acid, hydrocyanic acid, ammonia, nitrous acid, and other oxygen compounds of nitrogen.

The author concludes from his observations that, with a slit burner or an argand, there is no volatile unburned carbon compound of neutral reaction such as hydrocarbon or carbonic oxide liberated in the combustion of gas. The incandescent burner allows small quantities of carbon to escape imperfectly burned, and this unburned portion may amount to 2 per cent. of the whole carbon, but even on the assumption that all the imperfectly burnt carbon were in the state of carbonic oxide the proportion of that gas would be too small to produce a poisonous effect, so that, at the worst, no danger is to be feared in using incandescent burners.

Besides carbonic acid and sulphurous acid no other volatile acids were found in the products of combustion in any appreciable amount. Special search was made for hydrocyanic acid with very doubtful, if not entirely negative, results. The average amount of sulphurous acid was 0.0942 per cent. by weight, or 0.687 grain, corresponding to 0343 grain sulphur, per cubic foot of gas. Of oxidation products of nitrogen, which are always formed when combustion takes place in moist air, the amount of nitrous acid found was 0.36 milligramme per 100 litres of air passed through the apparatus in which the gas was burnt with the slit burner, 0.4 with the argand, and 0.22 with the incandescent burner, the air being so highly charged with products of combustion as to contain from 2 to 3 per cent. of carbonic acid. Special search was made for arsenic that might have come from pyrites in the coal, but no trace of it was detected.

The water condensed is slightly lighter than pure water; it is slightly acid, and becomes greenish yellow when neutralised with ammonia. The quantity of sulphuric acid found was 0.0012 per cent., that of sulphurous acid 0.0042 per cent. with the slit burner, 0.0053 and 0.0048 with the argand, 0.0048 and 0.0078 with the incandescent burner, the possible quantity of sulphuric acid being 0.2683 per cent., so that only about 2 per cent. of the sulphur at once forms sulphuric acid, the greater part passing on as sulphurous acid in the gaseous state There was no ammonia or hydrocyanic acid in the condensed water, but some trace of nitrous acid. The condensed water also contained a small proportion of organic material, pro bably derived from atmospheric dust, but it was ascertained to be quite innocuous.

Experiments in which animals were made to breathe air containing the products of combustion were carried out without any indications of injurious effects, even when the air was so highly contaminated with the products of combustion from good gas burners as to contain from 1.to 3 per cent. carbonic acid. There was no evidence of absorption of carbonic oxide or of the action of nitric acid upon the blood.

By testing the air in rooms lighted with gas under varying conditions of ventilation it was ascertained that to have as much as 1 per cent. carbonic acid in the air of a room is perfectly exceptional; an amount of from 0.6 to 0.8 per cent. may be reached in an unventilated room, but in a well ventilated room 0.2 or 0.3 per cent. can scarcely be exceeded, even when gas is burnt with extravagant superfluity. The carbonic acid takes the place of an equal volume of oxygen, but the researches of Paul Bert, Friedländer, Herther, Speck, and others, have shown that the replacement of oxygen by carbonic acid to the extent of 1 per cent. is unimportant as regards health or comfort. The author's experiments show that even 3 per cent. makes no difference in these respects, but that applies only to pure carbonic acid, and not necessarily to carbonic acid mixed with other products of combustion, and the amount of such products is not indicated by or proportional to that of carbonic acid.

The amount of sulphurous acid in the air respired scarcely reaches 0.001 or at most 0.015 per cent. by volume when the gas burnt contains 310 to 345 grains of salphur per 1,000 cubic feet. According to Lehmann and Hirt, that proportion has no importance from a hygienic point of view. In a well ventilated room the proportion falls to 0.2 or 0.4 per $1,000,000$ cubic feet. 